\title{
Chitosanase Production by Paenibacillus ehimensis and its Application for Chitosan Hydrolysis
}

\author{
Maria Giovana Binder Pagnoncelli ${ }^{1 *}$, Nathália Kelly de Araújo ${ }^{1}$, Nayane Macêdo Portela \\ da Silva ${ }^{1}$, Cristiane Fernandes de Assis ${ }^{1}$, Sueli Rodrigues ${ }^{2}$ and Gorete Ribeiro de Macedo ${ }^{1}$ \\ ${ }^{1}$ Laboratório de Engenharia Bioquímica; Departamento de Engenharia Química; Universidade Federal do Rio \\ Grande do Norte; 59072-970; Natal - RN - Brasil. ${ }^{2}$ Departamento de Tecnologia de Alimentos; Universidade \\ Federal do Ceará; C. P.: 12168; 60021-970; Fortaleza - CE - Brasil
}

\begin{abstract}
The chitosanase production by Paenibacillus ehimensis was studied in submerged cultures and the chitosan hydrolysis was evaluated by using these enzymes without purification. The bacterium produced inducibles enzymes after 12 h of growth in a culture medium containing $0.2 \%(w / v)$ of soluble chitosan as carbon source. The enzyme production was strongly repressed by the presence of glucose. The production started as soon as the available sugars finished in the culture medium. The maximum level of chitosanase activity was 500 U.L ${ }^{-1}$ at $36^{\circ} \mathrm{C}$ after $36 \mathrm{~h}$ incubation. The crude enzyme was optimally active at $\mathrm{pH} 6.0$ and $55^{\circ} \mathrm{C}$ and in these conditions, the enzyme presented good stability (6 days). The enzyme without purification was used to hydrolyze the chitosan which resulted chitooligosaccharides between 20 and 30 min of reaction.
\end{abstract}

Key words: Chitosanase, Paenibacillus ehimensis, chitosanase production, crude enzymes and TLC

\section{INTRODUCTION}

Chitosan, a D-glucosamine polymer, is a totally or partially deacetylated derivative of chitin. Chitin can be extracted from shrimp or crab shells and is second most abundant polysaccharides in the nature, with an annual production of $10^{10}$ to $10^{11}$ tons (Kumar, 2000; Kurita, 2001). The accumulation of large amounts of crustaceans processing discard has become a major concern in the seafood processing industry. This waste has been a challenge for shellfish-production. Therefore, the production of high added-value products, such as, chitin, chitosan and their derivatives along with their application in different fields are of utmost interest (Shahidi et al. 1999).
Chitosan and its derivatives showed functional properties making them useful in many fields including, food, cosmetics, medicine and pharmaceuticals (Shahidi et al. 1999; Kim and Rajapakse, 2005). However, its poor solubility makes the chitosan difficult to be used in food and biomedical applications. On the other hand, chitosan oligosaccharides (COS) are readily soluble in water due to their shorter chain lengths and free amino groups in the D-glucosamine units (Li et al. 2005). COS, composed of 2 to 10 units of D-glucosamines, are easily absorbed in the intestine and quickly get into the blood flow. COS also present a systemic biological effects in the organism, such as antitumor, prebiotic and

*Author for correspondence: giobinder@eq.ufrn.br 
antimicrobial activities (Kim and Rajapakse, 2005).

Conversion of chitosan into COS can be done either by acid or enzyme hydrolysis. Chemical hydrolysis is carried out at high temperatures under highly acidic conditions, resulting in a large amount of glucosamine (chitosan monomer), due to the difficulties in the formation process control. Therefore, this method produces low yields of pentamers and hexamers. Enzymatic hydrolysis has some advantages in producing COS. Chitosanases can catalyze the hydrolysis under mild conditions (Kuo et al. 2004; Ming et al. 2006) Chitosanases have been recognized as enzymes that attack chitosan but not chitin and defined as the enzyme performing endohydrolysis of $\beta-1,4-$ linkages between D-glucosamine residues in a partly acetylated chitosan ( $\mathrm{Su}$ et al. 2006). Chitosanase has been found in a variety of microorganisms, including various bacterial species (Kurakake et al. 2000; Choi et al. 2004; Kim et al. 2004; Su et al. 2006; Sun et al. 2007; Zhu et al. 2007; Gao et al. 2008; Wang and Yeh, 2008; Wang et al. 2008a; Wang et al. 2008b) and fungi (Chen et al. 2005; Ike et al. 2007).

Although, microbial chitosanases shows excellent performances in COS production, they are expensive to be utilized in large-scale industrial applications, because enzyme hydrolysis requires multi-steps, particularly, enzyme preparation and purification.

In an attempt to obtain a chitosanase which could be used without purification for chitosan oligomers production, a bacterium isolated from soil rich in chitin was employed in this work. The induction and the production of chitosanolitic enzymes from Paenibacillus ehimensis were studied. The chitooligosaccharides obtained using these crude enzymes and the enzymes stability were also evaluated.

\section{MATERIALS AND METHODS}

\section{Microorganism and maintenance of culture}

The bacterial strain used in this study was the Paenibacillus ehimensis NRRL B-23118, previously isolated from a soil sample collected in Japan (Kuroshima et al. 1998). The strain was activated in nutrient broth for $48 \mathrm{~h}$ at $36^{\circ} \mathrm{C}$. For the maintenance, the supernatant was removed by centrifugation at $2500 \mathrm{rpm}$ for $15 \mathrm{~min}$ at $20^{\circ} \mathrm{C}$ and
$1.5 \mathrm{~mL}$ of $10 \%(\mathrm{v} / \mathrm{v})$ glycerol solution was added on the bacterial cells and they were stored at -20 and $-196^{\circ} \mathrm{C}$.

\section{Materials}

Chitosan was purchased from Sigma-Aldrich Co. (St. Louis, Mo.). Other reagents were of analytical grade.

\section{Preparation of soluble chitosan}

Soluble chitosan was prepared as follows: $10 \mathrm{~g}$ of powder chitosan was suspended and dissolved through stirring in $1 \mathrm{~L}$ of $\mathrm{HCl}$ solution $(0.1 \mathrm{M})$. Insoluble materials were removed by filtration through sintered glass filter and the $\mathrm{pH}$ of the solution was adjusted to 7.0 by wise drop addition of $10 \mathrm{~N} \mathrm{NaOH}$ for enzyme production and 6.0 for oligosaccharides production (Choi et al. 2004).

\section{Enzyme production in submerged cultures}

For the production of chitosanase, the culture medium consisted (g. $\left.\mathrm{L}^{-1}\right)$ : peptone 6.0, yeast extract 6.0, glucose 1.0, $\mathrm{K}_{2} \mathrm{HPO}_{4} \quad 1.0$, $\mathrm{MgSO}_{4} .7 \mathrm{H}_{2} \mathrm{O} 0.5$ and soluble chitosan 2.0. The initial $\mathrm{pH}$ was adjusted to 7.0 with $\mathrm{NaOH}$ and the medium was sterilized by autoclaving at $121^{\circ} \mathrm{C}$ for $15 \mathrm{~min}$. The above medium $(45 \mathrm{~mL}$ in $250 \mathrm{~mL}$ Erlenmeyer flasks) was inoculated with $5 \mathrm{~mL}$ of a pre-culture in exponential growing phase as previously defined (Pagnoncelli et al. 2007) and incubated on an orbital shaker at $36^{\circ} \mathrm{C}$ and 120 rpm. Triplicate flasks were withdrawn at regular intervals and analysed for reducing sugars, enzymatic activity and $\mathrm{pH}$. Then the contents were centrifuged at $12.000 \mathrm{rpm}$ for $15 \mathrm{~min}$ and the cellfree supernatant was used for analysis.

\section{Enzyme assay}

Chitosanase activity was assessed in triplicate by measuring the reducing sugars produced from chitosan hydrolysis. Five hundred microliters of the supernatant (crude enzymes) was mixed with $500 \mu \mathrm{L}$ of soluble chitosan ( $\mathrm{pH}$ 6.0), and the reaction mixture was incubated for $30 \mathrm{~min}$ at $55^{\circ} \mathrm{C}$. To stop the reaction, $2.5 \mathrm{~mL}$ of dinitrosalicylic acid was added and the reducing sugars were measured immediately by using DNS method (Miller, 1959) with D-glucosamine as the standard. One unit of chitosanase was defined as the amount of enzyme that released $1 \mu \mathrm{mol}$ of Dglucosamine per minute under the conditions described above. 
Effect of temperature on chitosanase activity To determine the optimum temperature, the supernatant and the soluble chitosan were incubated at $30-85^{\circ} \mathrm{C}$ for $30 \mathrm{~min}$ in acetate buffer $(\mathrm{pH}$ 6.0). The reducing sugars were measured immediately by using DNS method.

\section{Effect of pH on chitosanase activity}

For the measurement of optimum $\mathrm{pH}$, the supernatant was incubated with soluble chitosan at 3.0 and 9.0 at $55^{\circ} \mathrm{C}$ for $30 \mathrm{~min}$. The reducing sugars were measured immediately by DNS method.

\section{Stability on chitosanase activity}

The thermal stability of the enzymes was investigated after incubating the supernatant for six days at $55^{\circ} \mathrm{C}$ in absence of the soluble chitosan (substrate) at $\mathrm{pH}$ 6.0, 7.5 and 9.0. Aliquots were sampled and the remaining activity was assayed at the optimum $\mathrm{pH}$ and temperature as previously determined.

\section{Analysis of hydrolytic product of soluble chitosan}

The reaction mixture, consisting of $2 \mathrm{~mL}$ of $1 \%$ (w/v) of soluble chitosan and $2 \mathrm{~mL}$ of supernatant (crude enzymes), was incubated at $55^{\circ} \mathrm{C}$ for $9 \mathrm{~h}$. The reaction was stopped by boiling for $10 \mathrm{~min}$, followed by centrifugation at $12.000 \mathrm{rpm}$ for 15 min and filtered. The COS mixture was analyzed by TLC. The reaction mixture $(30 \mu \mathrm{L})$ was spotted on silica gel 60 plates (Merck) and developed in a solvent system composed of n-butanol: 30\% ammonia water (2:1, v/v) (Choi et al. 2004). COS standard (obtained from Seikagaku Co) were run in parallel to the COS mixture. After solvent development, plate was dried by hot air and immersed in a saturated silver nitrate solution $(0.7$ $\mathrm{g} / 200 \mathrm{~mL}$ acetone). Plate was dried by hot air again and COS were detected by spraying the plate with $0.5 \mathrm{~N}$ sodium hydroxide/ethanol solution then heating at $80^{\circ} \mathrm{C}$ for $20 \mathrm{~min}$ (Hsiao et al. 2008).

\section{RESULTS AND DISCUSSION}

\section{Enzyme production}

Figure 1 shows the time-course profile of chitosanase production by $P$. ehimensis in a basal medium containing soluble chitosan. Chitosanase production started after the total glucose consumption by the microorganism, reaching a

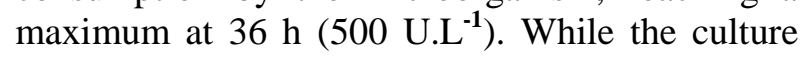
medium had glucose as carbon source, the enzyme production induction was not seen and it started when the glucose levels dropped to 0.2 g.L. $\mathrm{L}^{-1}$. Thus, the chitosanase produced by $P$. ehimensis was inducible like most of reported chitosanases. These enzymes might be synthesized in the presence of either their substrate in the surrounding medium or compounds structurally related to them, a behaviour common in all the inducible enzymes (Suto and Tomita, 2001; Costa et al. 2008).

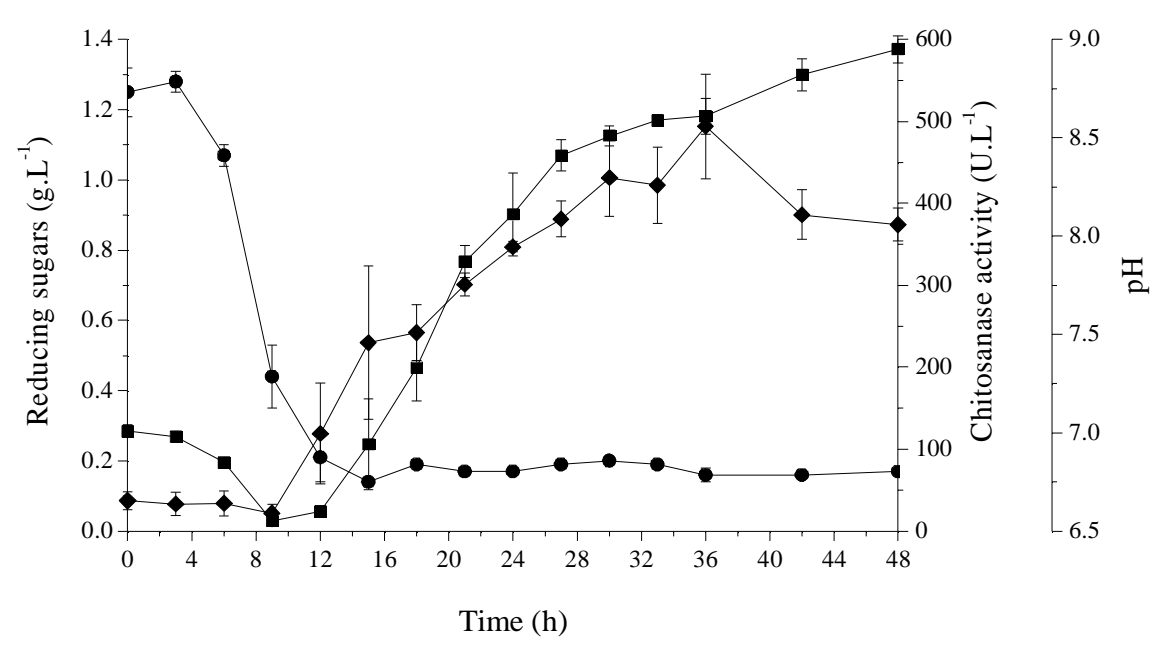

Figure 1 - Chitosanase production, reducing sugar consumption and $\mathrm{pH}$ as a function of cultivation time of Paenibacillus ehimensis grown at $36^{\circ} \mathrm{C}$ on soluble chitosan in shake flasks. ( $\left.\mathbf{a}\right)$ $\mathrm{pH},(\bullet)$ reducing sugar and $(\bullet)$ chitosanase activity. 
The $\mathrm{pH}$ of the medium initially dropped as glucose consumption started, but as soon as the enzyme production was initiated, the $\mathrm{pH}$ started to rise. This indicated that some organic nitrogen was being consumed with consequently ammonia formation. It was observed that during the enzyme production in the absence of simple sugars such an amylase, chitinase and chitosanase, the microorganisms needed to use the nitrogen sources for energy. The subsequent decrease in the enzyme activity after $36 \mathrm{~h}$ could probably be due to the inactivation of the enzymes by other constituent such as proteases (Sumantha et al. 2006). Kinetics studies of chitosanase and chitinase production by Sphingomonas sp. CJ-5 and Pseudomonas sp TKU 015 and chitosanase production by Microbacterium sp OU01 and Serratia marcescens TKU011 have shown the same behavior (Sun et al. 2007; Zhu et al. 2007; Wang et al 2008a; Wang et al, 2008b). This way the chitosanase activity obtained by these microorganims should not be compared to the activity obtained using the enzymes produced by $P$. ehimensis because the reaction conditions were different, like the substrate added in the reaction and the time of the reaction.

Chitosanase produced by Pseudomonas sp TKU 015 after $72 \mathrm{~h}$ had a chitosanase activity of 25 mU.mL ${ }^{-1}$, and after 30 minutes in contact with a $1 \%$ chitosan solution, the relation between substrate and enzyme was 2:1 (Wang et al 2008a). Best results were obtained using chitosanase from Sphingomonas sp. CJ-5, 0.9 U.mL ${ }^{-1}$ after 30 minutes, in the same conditions using the enzymes produced by $P$. ehimensis, but the enzyme production reaching a maximum only after $96 \mathrm{~h}$ (Zhu et al. 2007). A 72 h old culture of Serratia marcescens TKU011 presented a chitosanse activity around $0.025 \mathrm{U} . \mathrm{mL}^{-1}$ which wan after 30 minutes of a enzyme / substrate (1:5) reaction. The highest level of chitosanase activity in the Bacillus cereus D-11 culture after cultivation for $72 \mathrm{~h}$ was 4.85 U.mL $\mathrm{mL}^{-1}$, but this activity was investigated after 30 minutes of enzyme / substrate (1:45) reaction (Gao et al. 2008). Chitosanase produced by Microbacterium sp OU01 after $96 \mathrm{~h}$ had a maximum chitosanase activity of $118 \mathrm{U} \cdot \mathrm{mL}^{-1}$, after 15 minutes in contact with a $1 \%$ chitosan solution, the relation between enzyme and substrate was 1:10 (Sun et al., 2007). The activity of the chitosanase produced by $P$. ehimensis was evaluated after 30 minutes and the relation between the substrate and enzyme was 1:1, and probably, with increasing the substrate the enzyme activity will also increase. In this work, the enzyme production conditions were satisfactory, since the most important was the time of oligosaccharide formation and the use of one enzyme without purification as well.

\section{Enzyme activity optimal conditions}

Chitosanases produced by others Bacillus sp. strains showed optimum activities at $\mathrm{pH}$ values between 4.0 and 8.0, the optimum temperatures of activity have been reported to be in the ranges 30$70^{\circ} \mathrm{C}$ (Kurakake et al. 2000; Aktuganov et al. 2003; Jo et al. 2003; Choi et al. 2004; Kim et al. 2004; Su et al. 2006; Gao et al. 2008; Wang and Yeh, 2008). The effect of $\mathrm{pH}$ and temperature on the catalytic activity of chitosanase from $P$. ehimensis was studied by using soluble chitosan as substrate changing the $\mathrm{pH}$ and temperature during the assay.

The enzyme activity was assayed at temperatures ranging from 30 to $85^{\circ} \mathrm{C}$ at a constant $\mathrm{pH}$ of 6.0 . Chitosanase presented constant activity from 50 to $75^{\circ} \mathrm{C}$ (Fig. 2). For practical purposes, further assays were carried out at $55^{\circ} \mathrm{C}$.

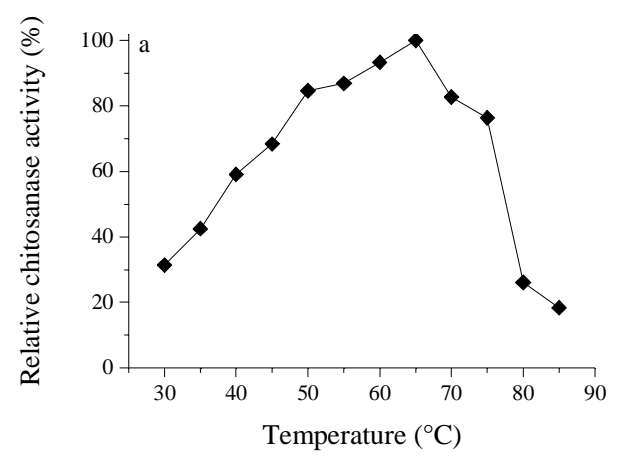

Figure 2 - Effect of temperature on chitosanase activity produced by Paenibacillus ehimensis. 
The effect of $\mathrm{pH}$ on the catalytic activity was studied by using chitosan as a substrate under the standard assay conditions. The experimental domain was set for $\mathrm{pH}$ between 3.0 and 9.0. The enzyme had an optimum pH at pH 6.0 (Fig. 3).

\section{Enzyme stability}

To determine the thermal stability of chitosanase produced by $P$. ehimensis, the residual activity was measured after incubation of the supernatant at various $\mathrm{pH}$ for 6 days at $55^{\circ} \mathrm{C}$ in the absence of substrate (soluble chitosan) and the residual activity was measured along the time (Fig. 4).

The chitosanase produced was stable at $\mathrm{pH} 6.0$, lost around 5\% activity at $\mathrm{pH} 7.5$ and $60 \%$ at $\mathrm{pH}$ 9.0.

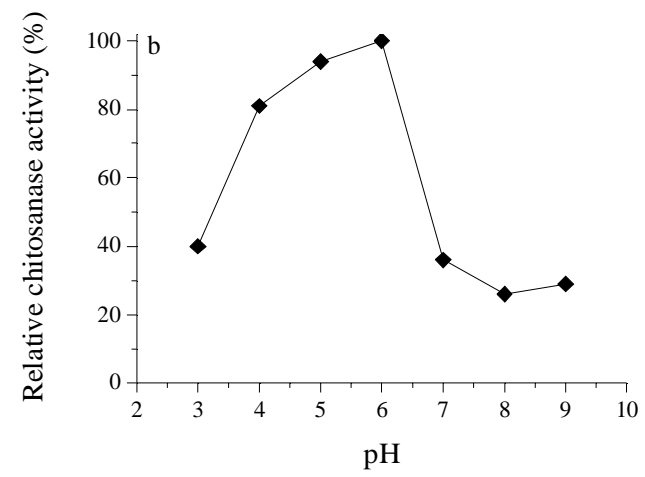

Figure 3 - Effect of $\mathrm{pH}$ on chitosanase activity produced by Paenibacillus ehimensis.



Figure 4 - Effect of temperature on the stability of chitosanase at pH $6.0(\bullet), 7.5(\diamond)$ and $9.0(\bullet)$.

Enzymes exposed to extremes $\mathrm{pH}$ and temperatures lose activity. Microbacterium sp OU01 produced two chitosanases, which lost the activity easily. One was optimally active at $50^{\circ} \mathrm{C}$ and the half-life was $30 \mathrm{~min}$, the other enzyme presented optimal temperature of $60^{\circ} \mathrm{C}$ and after 20 min half activity was detect (Sun et al. 2006). After purification, chitosanase produced by Serratia marcescens TKU011 presented the optimum temperature of $60^{\circ} \mathrm{C}$, but was rapidly inactivated retaining only $60 \%$ of its initial activity after $60 \mathrm{~min}$ at this temperature (Wang et al. 2008b). Chitosanase purified from the culture of Pseudomonas sp TKU011 presented $40 \%$ of activity lose when exposed for $30 \mathrm{~min}$ at $50^{\circ} \mathrm{C}$ (Wang et al. 2008a). Purified chitosanases produced by $B$. cereus $\mathrm{S} 1$ exposed for $30 \mathrm{~min}$ at $50^{\circ} \mathrm{C}$ lost $35 \%$ of enzyme activity. Enzyme exposition for the same time at $60^{\circ} \mathrm{C}$ resulted in complete enzyme denaturation (Kurakake et al. 2000). Purified chitosanases produced by Bacillus sp. KCTC 0377BP showed maximum activity at 
$60^{\circ} \mathrm{C}$, but in 5 min exposure at this temperature, the activity was half reduced (Choi et al. 2004). Purified enzymes produced by $B$. subtilis showed optimal activity at $37^{\circ} \mathrm{C}$ and after $60 \mathrm{~min}$, half activity was lost (Wang and Yeh, 2008). Purified enzyme from Bacillus sp. MET 1299 showed optimal activity at $60^{\circ} \mathrm{C}$ and after $60 \mathrm{~min}, 80 \%$ of activity was lost (Kim et al. 2004). The crude chitosanases produced by $P$. ehimensis showed higher stability at optimal activity condition compared to purified chitosanases produced by other microorganisms. The high stability of the enzyme is important for industrial applications of the crude enzymes, which could reduce the process costs.

\section{Analysis of chitosanase hydrolytic products of soluble chitosan}

The products obtained by enzymatic hydrolysis of soluble chitosan using the crude chitosanases from
P. ehimensis (supenatant) were analyzed by TLC (Fig. 5). The synthesis was carried out at $\mathrm{pH} 6.0$ and $55^{\circ} \mathrm{C}$ (optimum activity conditions) containing $1 \%(\mathrm{w} / \mathrm{v})$ of soluble chitosan. Chitosan was hydrolyzed to $(\mathrm{GlcN})_{2}$ and $(\mathrm{GlcN})_{6}$ at the initial stage of the reaction. After incubation for $2 \mathrm{~h}$, the amounts of $(\mathrm{GlcN})_{2}$ and $(\mathrm{GlcN})_{3}$ in the hydrolysates increased.

COS was obtained after 20 min of reaction and their maximum concentration (visualized by the spot intensity on TLC plate) was obtained between 20 and 30 min of reaction. The crude chitosanase enzyme complex from $P$. ehimensis produced COS with different sizes, suggesting that the mode of action of the enzyme was endo-type (Chen et al. 2005). The crude enzymes resulted in COS profile comparable to that obtained using purified chitosanases produced by other microorganisms (Kim et al. 2004; Ike et al. 2007).

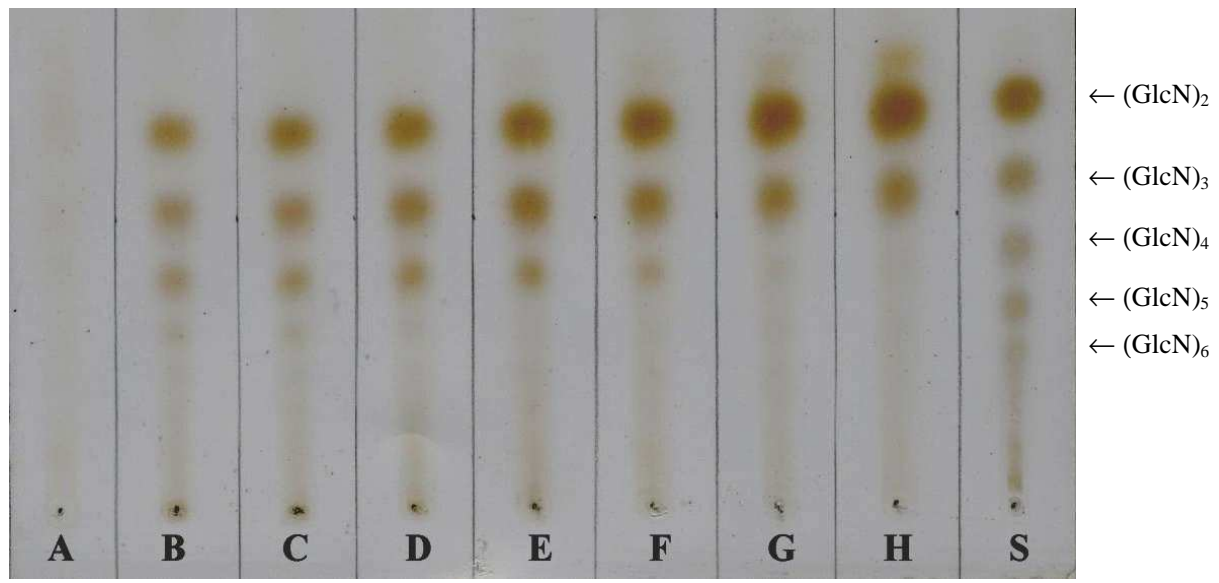

Figure 5 - TLC profiles of chitooligosaccharides produced in the hydrolysis of soluble chitosan by crude chitosanase from Paenibacillus ehimensis. Lane A-H, present hydrolysates obtained after enzyme reaction for 10, 20, $30 \mathrm{~min}, 1,2,3,6$ and $9 \mathrm{~h}$; Lane S, COS standard.

\section{CONCLUSIONS}

In this work, the inductive chitosanase effect of chitosan on P. ehimensis B- 23118 was observed. The chitosanase obtained by this microorganism showed maximum activity at $\mathrm{pH} 6.0$ at $50-70^{\circ} \mathrm{C}$. Thus, $55^{\circ} \mathrm{C}$ was chosen as the optimum temperature for further assays. Crude enzyme showed good stability at optimum activity conditions being suitable for direct utilization without purification.

The crude chitosanases hydrolyzed soluble chitosan into biofunctional oligomers (COS). The use of crude enzymes instead purified ones, are of industrial interest because enzyme purification steps are expensive steps in industrial enzyme production. Crude chitosanase from $P$. ehimensis B-23118 showed good industrial potential. 


\section{ACKNOWLEDGEMENTS}

The authors thank CNPq (Conselho Nacional de Pesquisa e Desenvolvimento Tecnológico) for the financial support and ARS culture collection for providing the microorganism strain.

\section{RESUMO}

A produção de quitosanases pelo Paenibacillus ehimensis foi estudada em culturas submersas e a hidrólise da quitosana foi realizada utilizando essas enzimas sem purificação. As enzimas foram obtidas após 12 horas de crescimento desta bactéria em meio de cultivo contendo $0,2 \%(\mathrm{p} / \mathrm{v})$ de quitosana solúvel como fonte de carbono. A produção das enzimas foi fortemente reprimida na presença de glicose, sendo obtida após o consumo total dos açúcares disponibilizados no referido meio de cultivo. A máxima atividade quitosanolítica foi obtida após 36 horas de cultivo a $36^{\circ} \mathrm{C}$, atingindo valores de 500 U.L. . As $^{-1}$ enzimas utilizadas no extrato bruto apresentaram melhores atividades quando submetidas a condições de $\mathrm{pH}$ e temperatura de 6,0 e $55^{\circ} \mathrm{C}$, respectivamente, e nessas condições permaneceram estáveis durante 6 dias. Essas enzimas sem serem submetidas aos processos de purificação foram utilizadas para hidrolisar a quitosana, obtendo os quito-oligossacarídeos entre 20 e 30 minutos de reação.

\section{REFERENCES}

Aktuganov, G. E.; Shirokov, A. V. and Melent'ev, A. I. (2003), Isolation and characterization of chitosanase from the strain Bacillus sp. 739. Appl. Biochem. Microbiol., 39, 469-474.

Chen, X.; Xia, W, and Yu, X. (2005), Purification and characterization of two types of chitosanase from Aspergillus sp CJ22-326. Food Research. Int., 38, 315-322.

Choi, Y. J.; Kim, E. J.; Piao, Z.; Yun, Y. C. and Shin, Y. C. (2004), Purification and characterization of chitosanase from Bacillus sp. strain KCTC 0377BP and its application for the production of chitosan oligosaccharides. Appl. Environ. Microbiol., 70, 4522-4531.

Costa, A. M.; Ribeiro, W. X.; Kato, E.; Monteiro, A. R. G. and Peralta, R. M. (2008), Production of tannase by Aspergillus tamarii in submerged cultures. Braz. Arch. Biol., 51, 399-404.
Gao, X.; Ju, W.; Jung, W. and Park, R. (2008), Purification and characterizaton of chitosanase from Bacillus cereus D-11. Carbohydr. Polym., 72, 513520.

Hsiao, Y. C.; Lin, Y. W.; Su, C. K. and Chiang, B. H. (2008), High degree polymerized chitooligosaccharides syntesis by chitosanase in the bulk aqueous system and reversed micellar microreactos. Process. Biochem., 43, 76-82.

Ike, M.; Ko, Y.; Yokoyama, K.; Sumitani, J. I.; Kawaguchi, T.; Ogasawara, W.; Okada, H. and Morikawa, Y. (2007), Cellobiohydrolase I (Cel7A) from Trichoderma reese $i$ has chitosanase activity. $J$. Mol. Catal. B: Enzym., 47, 159-163.

Jo, Y. Y.; Jo, K. J.; Jin, Y. L.; Kim, K. Y.; Shim, J. H.; Kim, Y. W. and Park, R. D. (2003), Characterization and kinetics of $45 \mathrm{kDa}$ chitosanase from Bacillus sp. P16. Biosc. Biotechnol. Biochem., 67, 1875-1882.

Kim, P. I.; Kang, T. H.; Chung, K. J.; Kim, I. S. and Chung, K. C. (2004), Purification of a constitutive chitosanase produced by Bacillus sp. MET 1299 with cloning and expression of the gene. FEMS Microbiol. Lett., 240, 31-39.

Kim, S. K. and Rajapakse, N. (2005), Enzymatic production and biological activities of chitosan oligosaccharides (COS): a review. Carbohydr. Polym., 62, 357-368.

Kumar, M. N. V. R. (2000), A review of chitin and chitosan applications. React. Funct. Polym., 46, 1-27.

Kuo, C. H.; Chen, C. C. and Chiang, B. H. (2004), Properties 'process characteristics of hydrolysis of chitosan in a continuous enzymatic membrane reactor. JFS E: Food Engineering and Physical., 69, 7, 332- 337.

Kurakake, M.; Yo-u, S.; Nakagawa, K.; Sugihara, M. and Komaki, T. (2000), Properties of chitosanase from Bacillus cereus S1. Curr. Microbiol., 40, 6-9.

Kurita K. (2001), Controlled functionalization of the polysaccharide chitin. Prog. Polym. Sci., 26, 19211971.

Kuroshima, K. I.; Sakane, T.; Takata, R. and Yokota, A. (1996), Bacillus ehimensis sp. nov. and Bacillus chitinolyticus sp. nov. new chitinolytic members of the genus Bacillus. Int. J. Syst. Bacteriol., 46, 76-80.

Li, J.; Du, Y.; Yang, J.; Feng, T.; Li, A. and Chen, P. (2005), Preparation and characterization of low molecular weight chitosan and chito-oligomers by a commercial enzyme. Polym. Degrad. Stab., 87, 441448.

Miller, G. L. (1959), Use of dinitrosalicylic acid reagent for determination of reducing sugars. Anal. Chem., 31, 426-428.

Ming, M.; Kuroiwa, T.; Ichikawa, S.; Sato, S. and Mukataka, S. (2006), Production of chitosan oligosaccharides by chitosanase directly immobilized on an agar gel-coated multidisk impeller. Biochem. Eng. J., 28, 289-294. 
Pagnoncelli, M. G. B.; Soares Júnior, A. B.; Cruz, P. P.; Araújo, N. K.; Rodrigues, S.; Macedo, G. R. (2007), Comportamento cinético do Bacillus ehimenis em cultivos em shaker. Paper presented at IV Iberoamerican Chitin Symposium, 6-9 May, Natal, Brasil.

Shahidi, F.; Arachchi, J. K. V. and Jeon, Y. J. (1999), Food applications of chitin and chitosans. Trends Food Sci Tech., 10, 37-51.

Su, C.; Wang, D.; Yao, L. and Yu, Z. (2006), Purification, characterization, and gene cloning of a chitosanase from Bacillus species strain S65. J. Agric. Food Chem., 54, 4208-4214.

Sumantha, A.; Deepa, P.; Sandhya, C.; Szakacs, G.; Soccol, C. R. and Pandey, A. (2006), Rice bran as a substrate for proteolytic enzyme production. Braz. Arch. Biol. Tech.,49, 843-851.

Sun, Y.; Han, B.; Liu, W.; Zhang, J. and Gao, X. (2007), Substrate induction and statistical optimization for the production of chitosanase from Microbacterium sp. OU01. Bioresource Technology, 98, 1548-1553.

Sun, Y.; Liu, W.; Han, B.; Zhang, J. and Liu, B. (2006), Purification and characterization of two types of chitosanase from a Microbacterium sp. Biotechnol. Lett., 28, 1393-1399.
Suto, M. and Tomita, F. (2001), Review: induction and catabolite repression mechanisms of cellulase in fungi. J. Biosci. Bioeng., 92, 305-311.

Wang, S. L.; Chen, S. J. and Wang, C. H. (2008a), Purification and characterization of chitinases and chitosanases from a new species strain Pseudomonas sp. TKU015 using shrimp shells as a substrate. Carbohydrate Research., 343, 1171-1179.

Wang, S. L.; Peng, J. H.; Liang, T. W. and Liu, K. C. (2008b), Purification and characterization of a chitosanase from Serratia marcescens TKU011. Carbohydr. Res., 343, 316-1323.

Wang, S. and Yeh, P. (2008), Purification and characterization of a chitosanase from a nattokinase producing strain Bacillus subtilis TKU007. Process Biochem., 43, 132-138.

Zhu, X. F.; Zhou, Y. and Feng, J. L. (2007), Analysis of both chitinase and chitosanase produced by Sphingomonas sp CJ-5. J. Zhejiang Univ. Sci. B, 8, 831-838. 